\title{
Retorika Ilyasa dan Alyasa di Ajang Aksi Asia Indosiar
}

\author{
Siti Nurjanah ${ }^{1 *}$, Yaya1 $^{1}$, \& Rojudin ${ }^{2}$ \\ ${ }^{1}$ Jurusan Komunikasi dan Penyiaran Islam, Fakultas Dakwah dan Komunikasi, UIN Sunan \\ Gunung Djati, Bandung \\ ${ }^{2} J u r u s a n$ Komunikasi dan Penyiaran Islam, Fakultas Dakwah dan Komunikasi, UIN Sunan \\ Gunung Djati, Bandung \\ *Email :Jannatul.Aila03@gmail.com
}

\begin{abstract}
ABSTRAK
Penelitian ini bertujuan untuk mengetahui bagaimana gestur Ilyasa dan Alyasa pada saat berceramah di ajang Aksi Asia Indosiar, bagaimana struktur materi ceramah yang disampaikan, dan gaya bahasa apa saja yang digunakan pada saat berceramah di ajang Aksi Asia Indosiar. Penelitian ini menggunakan teori model komunikasi Aristoteles. Asumsi dasarnya yaitu speaker - message - listener. Metode yang digunakan adalah metode deskriptif dengan jenis data kualitatif. Hasil dari penelitian tersebut dapat diketahui bahwa gestur Ilyasa dan Alyasa yaitu meliputi badan yang berdiri tegak saat berceramah, nsmun terkadang sedikit membungkuk, sambil menghadap kepada audiens, dan bergantian tempat sesuai apa yang disampaikanya. Gerakan tangan saat berceramah mengikuti sesuai apa yang disampaikan, seringkali mereka menggerakan telunjuk ke atas, kanan, kiri, dan ke depan secara kompak. Adapun ekspresi yang terkandung meliputi mimik wajah dan pandangan mata. ILAL tidak hanya fokus kepada audience ataupun dewan juri saja, sesekali mereka melihat kepada kamera. Struktur materi yang disampaikan terdapat judul, pendahuluan, isi, dan penutup. Gaya bahasa yang digunakan mengandung beberapa majas dari gaya bahasa perbandingan, perulangan, sindiran, pertentangan, dan penegasan.
\end{abstract}

Kata Kunci : Retorika; Gestur; Gaya Bahasa.

\section{ABSTRACT}

This study aims to determine how the gesture of Ilyasa and Alyasa during the lecture at the Asia Indosiar Action event, how the structure of the material delivered, and what style of language is used when speaking at the Indosiar Asia Action event. The choice of the theory used in this study is Aristotle's communication model theory. The basic assumption is that the speaker - message - listener. The method used is descriptive method with qualitative data types. The results of this study can be seen that the gesture of Ilyasa and Alyasa which includes posture that stands upright, sometimes slightly bent, facing the audience, and move according to 
what he said. The movements of the hands when lecturing follow what is said, often they move their indexes upward, right, left, and forward in a compact manner. The expressions contained include facial expressions and eyesight. Ilyasa and Alyasa does not only focus on the audience or the jury, they occasionally look at the camera. The structure of the material presented is title, introduction, content, and closing. The style of language used contains several styles of comparative language styles, repetitive, satirical, contradictory, and affirmative.

Keywords : Rhetoric; Gesture; Language style.

\section{PENDAHULUAN}

Berbicara dihadapan umum yang dapat meningkatkan kualitas eksistensi bukan hanya berbicara, melainkan berbicara yang atraktif, bernilai informatif, menghibur, serta persuasif. Dengan kata lain berbicara berdasarkan seni yang dikenal dengan istilah retorika. Retorika adalah seni berkomunikasi secara lisan yang dilakukan oleh seseorang kepada sejumlah orang banyak dengan cara bertatap muka. Kata lain dari retorika yaitu pidato (Abidin 2003:17).

Dengan arti luas bahwa untuk seorang mubaligh yang mempunyai ilmu agama yang mumpuni jika pada saat meyampaikan pesan ceramah tidak cukup dengan penyampaian yang serius, karena tidak semua jamaah mudah untuk menerima pesan-pesan ceramah hanya dengan point-point ilmu agama saja, perlu selingan-selingan hiburan dan perumpamaan kata-kata dalam penyampaianya.

Kita pun seringkali melihat orang yang berpidato panjang lebar namun tanpa memperoleh apa-apa dari mubaligh malah memunculkan kelelahan dan kebosanan. Ini biasanya di sebabkan mubaligh mempunyai bahan yang banyak tetapi tidak mampu mengorganisasikanya. Pakaian yang acak-acakan menjengkelkan penonton betapa pun mahalnya bahan yang dipergunakan. Pidato yang tidak teratur bukan saja menjengkelkan penonoton, tetapi membuat bingung pembicaranya itu sendiri (Rahmat, 2011:31).

Dalam penyampaian pesan ceramah jika mubaligh menggunakan karakteristik berbicara sesuai dengan ilmu retorika dan gaya bahasa secara sempurna, maka jamaah dapat dipengaruhi oleh ajaran-ajaran yang telah mubaligh sampaikan bahkan feedbacknya akan sesuai dengan yang mubaligh harapkan.

Media adalah suatu alat yang digunakan masyarakat kapitalis dalam memasarkan produk budaya dan menciptakan gaya hidup materialis, pragmatis, hedonis dan bahkan konsumtif. Bentuk media sangat beragam, seperti televisi, radio, internet, surat kabar, majalah dan sebagainya yang digunakan sebagai sarana menyebarluaskan informasi kepada masyarakat modern. Namun demikian media televisi merupakan salah satu media paling utama yang dapat diakses, dinikmati, dan mudah terjangkau oleh seluruh lapisan masyarakat (Wahid, 2015: 
1).

Beberapa tahun belakangan televisi sudah dipakai para dai untuk menyampaikan pesan dakwahnya. Mengingat media televisi salah satu media yang paling praktis, mudah, meriah, dan cepat dalam menyajikan pesan dakwah. Selain itu televisi dapat memberikan hiburan, penerangan, sekaligus pendidikan (Dulwahab, 2016: 1).

Aksi Asia adalah suatu ajang pencarian dakwah yang ditayangkan oleh Indosiar selama bulan puasa di waktu sahur. Para peserta pada saat berceramah tentu beretorika dengan menggunakan gaya ceramah dan metode-metode yang berbeda-beda, walaupun demikian penulis tertarik untuk meneliti gaya retorika ceramah pada salah satu peserta yang berhasil mencetak sejarah dengan mengharumkan nama bangsa dengan meraih gelar juara pertama Aksi Asia yaitu Ilyas dan Alyasa yang terkenal dengan sebutan Ilal.

Ilyasa dan Alyasa berhasil meraih poin tertinggi mengalahkan peserta dari negara Asia lain dengan ceramahnya yang kekinian dan ditunjang dengan berbagai pemilihan kata yang tepat serta gestur yang menarik. Maka dari itu penulis merumuskan beberapa masalah dengan fokus penelitian: Bagaimana gestur Ilyasa dan Alyasa di ajang Aksi Asia Indosiar? Bagaimana struktur materi ceramah yang disampaikan? Bagaimana gaya bahasa Ilyasa dan Alyasa saat berceramah di Aksi Asia Indosiar?. Dalam penelitian ini menggunakan metode deskriptif dan teknik pengumpulan diperoleh dari hasil observasi, wawancara, dan studi dekumentasi. Sedangkan jenis data yang digunakan yaitu data kualitatif, penulis mengambil 10 video di youtube yang menampilkan Ilal saat berceramah di ajang Aksi Asia Indosiar sebagai bahan analisis.

\section{LANDASAN TEORITIS}

Teori yang digunakan dalam landasan penelitian ini adalah Teori komunikasi model Aris Toteles yakni komunikasi paling klasik, yang sering juga disebut model retoris rhetorical model (Mulyana 2017: 146).

\section{Unsur Proses Komunikasi Menurut Aristoteles}

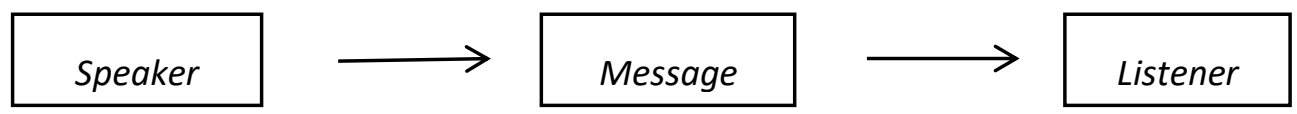

Fokus komunikasi Aristoteles ini adalah komunikasi retoris, yang kini lebih di kenal dengan komunikasi publik (public speaking) atau pidato. Aristoteles ini mengungkapkan bahwa persuasi dapat dicapai oleh siapa yang menyampaikan (ethos-keterpercayaan), argumen atau yang disampaikan (logos-logika dalam pendapat), dan dengan memainkan emosi khalayak (pathos-emosi khalayak). Dengan kata lain, faktor-faktor yang memainkan peran dalam menentukan efek persuasif suatu pidato, susunanya, dan cara penyampaianya. Aristoteles juga 
menyadari peran khalayak pendengar. Persuasi berlangsung melalui khalayak ketika mereka di arahkan oleh pidato itu ke dalam suatu keadaan emosi tertentu.

Secara etimologi, rhetoric atau dalam bahasa Indonesia retorika berasal dari bahasa latin yaitu rhetorica yang artinya seni bericara "The Art Of Speech" ( Moede, 2001:38). Secara terminologi, banyak sekali definisi retorika yang dibuat oleh para pakar retorika. Hal tersebut dikarenakan retorika mengalami sejarah dan perkembangan yang sangat panjang. Retorika sebagai ilmu yang mempelajari mengenai berbicara dengan baik dihadapan orang banyak. yakni ilmu yang membicarakan mengenai cara-cara berbicara didepan massa dengan tutur bicara yang baik agar mampu mempengaruhi para pendengar untuk mengikuti paham atau ajaran yang dipeluknya (Syukir, 1983:104).

Retorika merupakan ilmu yang di dalamnya menerangkan tentang seni berbicara, berbicara tidak lepas dengan kegiatan komunikasi dan retorika sebagai metode untuk menambah variasi dan mengindahkan kaidah seni berbicara tersebut. Banayak orang yang menganggap bahwa retorika itu berbicara di muka umum (public speaking). Hal ini memang benar tapi tidak seluruhnya benar. Karena secara logatiah berasal dari kata yunani "rethor" yang berarti orator (inggris), Orator berarti ketangkasan bicara.

Tujuan retorika itu menyampaikan ide, pikiran dan perasaan kepada dengan begitu mereka mengerti apa yang kita sampaikan. Lebih jauh, tujuan retorika bersifat persuasif, artinya melalui retorika diharapkan orang lain dapat mengikuti kehendak dan tujuan rhetor (Dewi, 2013:61). Sedang fungsi retorika adalah untuk membimbing penutur mengambil kepurusan yang tepat, memahami masalah kejiwaan manusia pada umumnya dan kejiwaan orang-orang yang kita hadapi, menemukan ulasan yang baik, dan mempertahankan diri serta mempertahankan kebenaran dengan alasan yang masuk akal (Abidin, 2013: 58).

Seperti yang telah dijelaskan oleh model komunikasi Aristoteles efek persuasif meliputi dari aspek isi pidato, penyusunanya, dan teknik penyampaianya. Pembahasan mengenai aspek isi pidato atau ceramah menurut Al Wisral Imam Zaidillah ada beberapa hal yang perlu di perhatikan : (1) memilih bahan yang tepat, (2) jangkauan ilmu tentang bahan tersebut, (3) menyusun secara sistematis, (4) menguasai bahan (Zaidillah, 2005 : 83).

Sedangkan dalam menyusun bahan ceramah adalah: judul, pendahuluan, isi, penutup yang mencakup dari kesimpulan dan saran-saran. Secara ringkasnya bentuk sistematika bagi penyusun suatu materi dakwah harus mengandung tiga bagian pokok : pendahuluan (muqaddimah) 10\%, tubuh isi Muhadharah (body of spech) 85\%, keaimpulan (conclution) 5\% (Zaidillah, 2005 : 84-86).

Berdasarkan dari bentuk isi materi menurut penjelasan di atas, mubaligh harus lebih menekankan isi materi ceramahnya dibandingan dengan penutup dan pendahuluanya, karena yang lebih penting dalam ceramah adalah tema materi 
S. Nurjanah. Yaya, dan Rojudin

ceramah dan isi materinya.

\section{HASIL DAN PEMBAHASAN}

Penelitian ini diperoleh dari televisi dan youtube. Aksi Asia Indosiar adalah sebuah acara religi yang terpusat ke ranah publik speaking atau pidato yang bertujuan menjadi tontonan dan tuntunan sekaligus sebuah ajang lomba dalam mencari untadz dan ustadzah baru yang memiliki karakter unik dalam menyampaikan dakwahnya. Acara realitas dan pencarian bakat ini ditayangkan di Indosiar selama bulan Ramadhan, setiap sahur selama bulan Ramdhan di ciptakan oleh programing Indosiar dan diproduksi oleh Tim produksi Indosiar. Aksi Asia merupakan program acara kombinasi antara reality dan variety show (Republika Online:2018). Disamping menyampaikan materi dakwah dan juga untuk menemani makan sahur, pada pukul 02:00 WIB sampai tiba Subuh.

Acara ini dibuat oleh Indosiar dengan tujuan yang mulia. Selain untuk mencari nafas dan memupuk nafas Islam yang positif, acara ini juga bertujuan menghimpun persaudaraan antara negara-negara di wilayah Asia, seperti Malaysia, Brunei Darussalam, Singapura, serta Timor Leste (posberitakota.com:2018).

Berdasarka penelitian yang diperoleh dari sepuluh video yang merekam semua kegiatan ceramah ILAL, setiap ceramahnya berdurasi kurang lebih lima sampai enam menit pada saat tampil di studio Aksi Asia Indosiar. Peneliti akan menjelaskan mengenai Gestur, struktur materi, dan gaya bahasa dari keseluruhan pidato yang dilihat.

Gestur Ilyasa dan Alyasa di ajang Aksi Asia Indosiar

Tabel 1 Gerak Tubuh Ilyasa dan Alyasa

Gerak Tubuh

Gestur atau sikap badan

Penampilan

Gerakan tangan

\section{Penelitian}

Berdiri tegap.

Namun terkadang sedikit membungkuk

menghadap kepada audience.

Berpindah tempat.

Penampilan mereka kompak.

Pakian rapih, layaknya orang kembar dengan memakai pakaian yang sama keduanya.

Gerakan tangan kompak.

Mengikuti sesuai apa yang disampaikan.

Kadang menggunakan telunjuk ke atas, kanan, kiri, dan ke depan sesuai apa yang disampaikan. 
Gerakan tangan Bergandengan tangan di setiap menyebutkan "kami berdua".

Hasil : Sumber penelitian

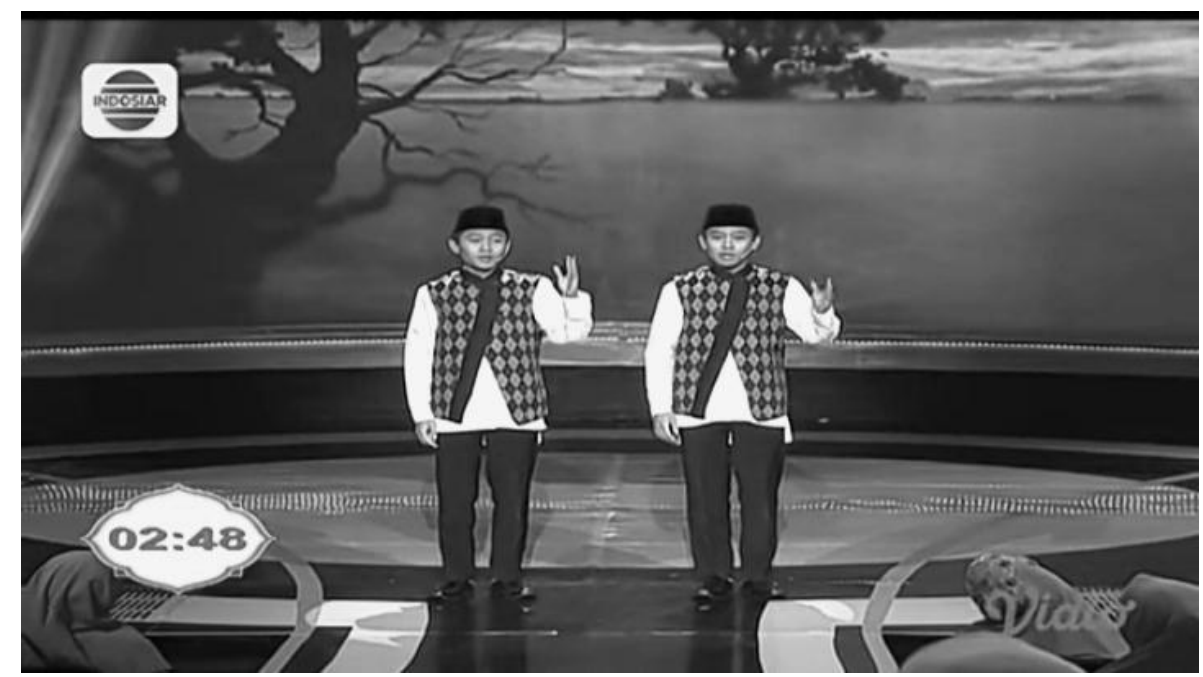

Sumber: Youtube

Gambar 1 Gestur Ilyasa dan Alyasa

Dalam gambar 1 tersebut Ilyasa dan Alyasa melantunkan ayat Al-qur'an beserta artinya dengan kompak sesuai kata-kata yang terucap seperti pada kalimat "syetan menakut-nakuti kamu yaitu dengan kemiskinan dan menyurub kalian berbuat kejahatan" adalah penggalan kalimat dari arti surat Al-Baqarah ayat 268. Dan terdapat juga pada kalimat selanjutnya yang di ucapkan secara bergantian yaitu "Dan Allah menunjukan kepadmu dengan ampunan dari-Nya karunia dan Allah maha luas lagi maha mengetahui".

Dari mulai video ke satu sampai sepuluh penulis teliti bahwa setiap melafalkan arti dari ayat $\mathrm{Al}$-qur'an tersebut selalu disertai dengan memakai gerakan, penulis ambil dari salah satu video yang ke empat yang berjudul "Jangan semena-mena" dengan ke unikan gerakanya tersebut terlihat Ustadz Soulmate sampai tidak bisa nahan tawa ketika ILAL menggunakan gerakan saat menyampaikan dari arti Qs. Al-Ahzab ayat 58:

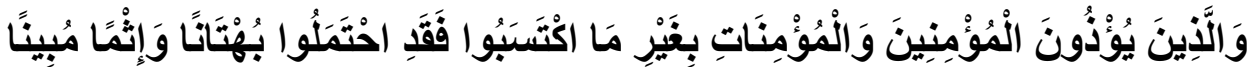

"Dan orang yang menyakiti orang-orang mukmin mukminat tanpa adanya kesalahan yang mereka perbuat, maka sesungguhnya mereka itu telah memikul kebohongan dan disertai dosa yang nyata". 
S. Nurjanah. Yaya, dan Rojudin

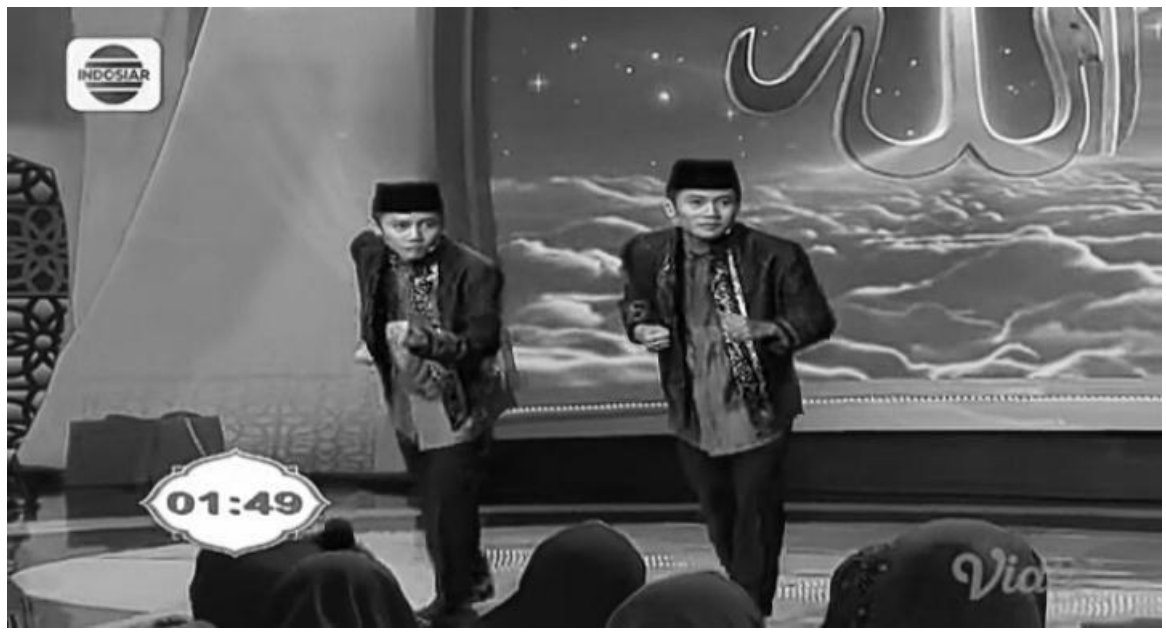

Sumber: Youtube

Gambar 2 Gestur Ilyasa dan Alyasa

Pada gambar 2 sambil berkata, Ilal mengayunkan kedua tanganya ke kiri dan ke kanan sesuai dengan apa yang mereka ucapkan, kemudian mengepalkan tanganya seolah-olah sedang memikul sesuatu dan membuka sepuluh jarinya. Begitupun pada kalimat lain.

Kalimat, "Memang khalwat disuatu tempat terasa nikmat karena tdk ada yg mencegat dan menggngu. Dem.. dem.. demdem.. Aman.. aman.. aman.. eh Pak. Aman". Mereka seperti jalan ditempat yang sedang bersembunyi dari kecurigaan orang, kemudian nengok kanan dan kiri dan ternyata kepergok orang.

Kemudian pada video ke tujuh: "W alaupun wajabnya tidak VIP tampilan pun pakai celana harga 100.000 kembalian 30.000, baju barga 100.000 kembalian 30.000, peci harga 80.000 kembalian 30.000. bergaya lah tapi jangan berlebihan, bergaulah, tapi jangan kebablasan, milikilah harta sebanyak-banyaknya tapi manfaatkan sebaik-baiknya". 


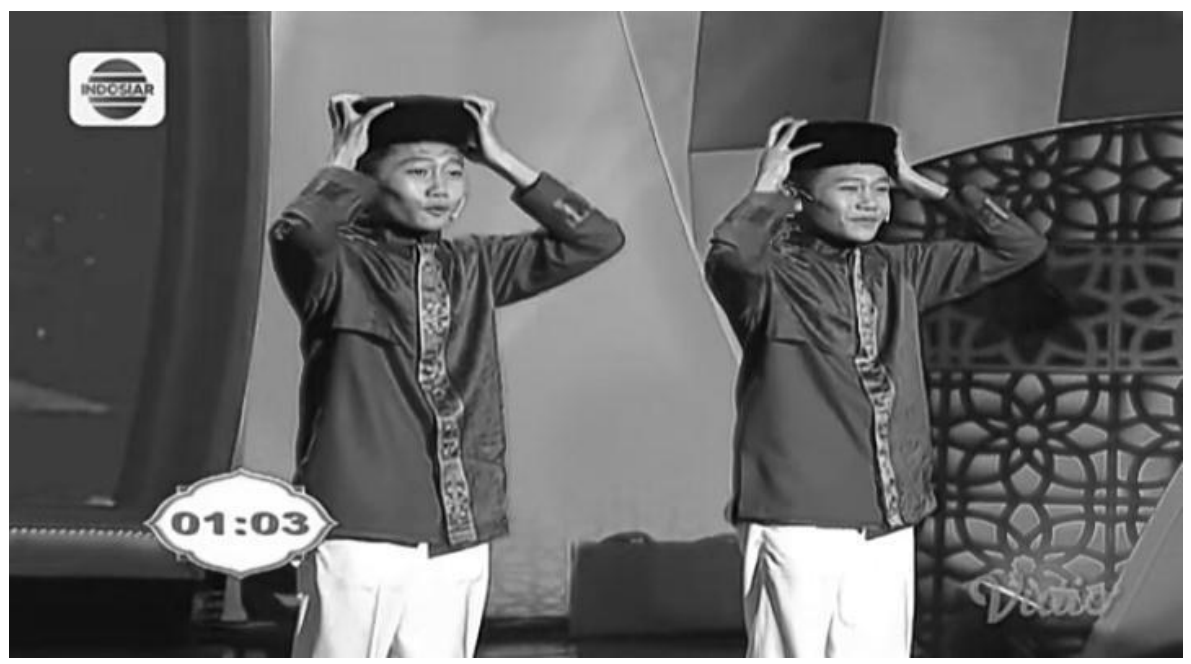

Sumber: Youtube

Gambar 3 Gestur Ilyasa dan Alyasa

Pada gambar $3 \mathrm{Al}$ berkata sambil memegang celana dan baju, sedangkan Il berkata "kembalian 30.000", seterusnya mereka mengangkat peci secara berbarengan dan diperlihatkanya kedepan sambil berkata berbarengan juga "kembalian 30.000".

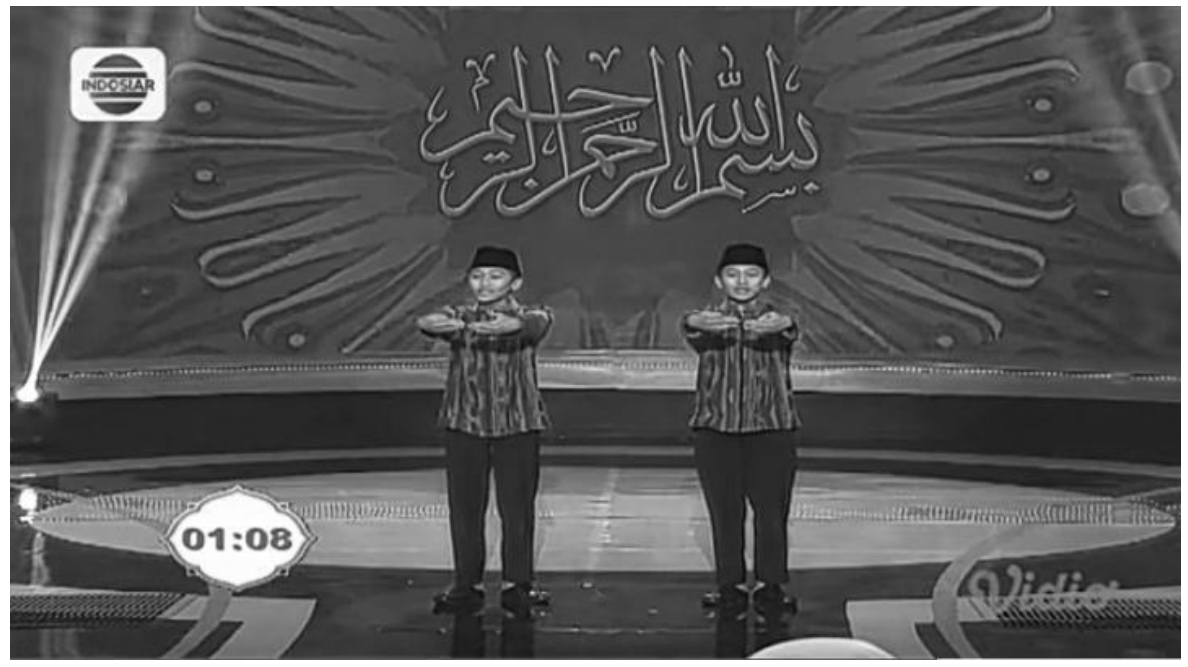

Sumber: Youtube

Gambar 4 Gestur Ilyasa dan Alyasa

Selanjutnya dalam gambar 4 terdapat syair lagu yang disampaikan di akhir ceramah. Berdasarkan penelitian penulis, dari video satu sampai sepuluh ILAL menyampaikan ceramah selalu di akhiri dengan lantunan sholawat atau syair lagu 
S. Nurjanah. Yaya, dan Rojudin

kecuali pada vodeo ke tiga. Pada setiap lagunya selalu memakai gerakan. Berikut ini penulis ambil dari gerakan lagu pada video yang ke satu dan ke delapan, yaitu terdapat pada lirik:

"Bissmillah... bissmillah in the name of Allah

Bissmillah... bissmillah dengan menyebut nama Allah

Dont't forget... don't forget never forget bissmillah

IL: Bissmillah... (mengangkat kedua tangan seperti orang berdo’a)

Al: before praying (mengangkat kedua tangan dengan maksud takbirotul ikhrom)

Il: bissmillah... (mengangkat kedua tangan seperti orang berdo'a)

Al: before sliping (kedua tangan menyentuh pipi sebelah kanan)

Il: Bissmillah... (mengangkat kedua tangan seperti orang berdo’a)

Al: before reading (menundukan kepala seperti orang yang sedang membaca)

Il: Bissmillah... (mengangkat kedua tangan seperti orang berdo’a)

Al: bissmillah before mancing (keduanya mempraktikan tangan yang sedang mancing)".

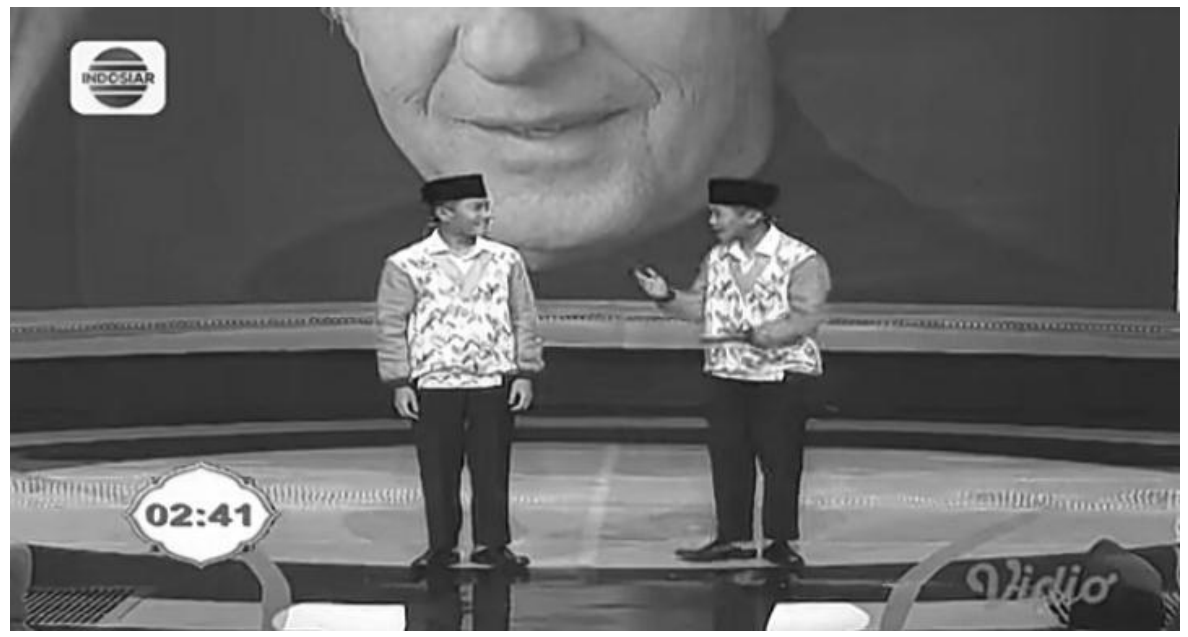

Sumber: Youtube

Gambar 5 Gestur Ilyasa dan Alyasa

Selain itu pada gambar 5 terdapat pada penggalan kalimat: "sepertiga untuke makananya, sepertiga untuk minumnya, sepertiga untuk nafasnya" tangan kiri di angkat sejajar dengan bahu, tangan kanan berada di pertengahan antara dada dan tangan 
kiri sambil menunjukan ketiga jarinya. Begitupun terdapat pada kalimat: "Makan adalah suatau cara untuk. menghilangkan rasa lapar, "Iilqodoi alal'ju" Menjaga kesehatan, "wal hafid ala sibah, dan menambah keknatan untuk beribadah, wajizadatul kunvah fil ibadab". Kedua tanganya memegang perut kemudian mengepalkan kedua tangan dan mempraktikan orang sholat.

\section{Struktur materi ceramah Ilyasa dan Alyasa di ajang Aksi Asia Indosiar}

Berdasarkan pendapat Alwisral Imam Zaidillah bahwa bentuk penyusunan bahan ceramah harus meliputi Judul, pendahuluan, isi, dan penutup (Imam Zaidillah, 20:84). Oleh karena itu penulis teliti pesan ceramah ILAL mengenai hal tersebut dari video satu sampai sepuluh sebagai berikut:

\section{Pertama, Judul}

Video ke satu "Tanpa Bissmillah, Amalan Bagai Domba tak Berkepala”.

Video kedua "Cukuplah Bagi Anak Adam Beberapa Suap Makanan".

Video ketiga "On Time On The Track".

Video keempat "Jangan Semena-Mena".

Video kelima "Jika Ada yang Menghina Sebenarnya Dialah Hina".

Video keenam "Jangan Takut Miskin".

Video ketujuh "In Heart On Heart".

Video kedelapan "Jangan Sepelekan hal Kecil".

Video kesembilan "Islam Mengatur Pergaulan Laki-Laki".

Video kesepuluh "Islam Ophobia".

\section{Kedua, Pendahuluan}

Dalam pendahuluan harus merupakan bara'atul istihlal yaitu membayangkan isi dan tujuan serta pentingnya pidato yang akan di ucapkan. Dalam ceramah ILAL dari video satu sampai sepuluh, setelah memberi salam dan muqoddimah selalu di awali dengan sapaan yang merupakan ciri khas mereka sebagai berikut:

"Nurrobib bisaadah majlisi tabkim, kama nurrobib bi sayyidah wa saadah majlisi ta'kib".

"Hadirin ejeung hadirot, tuan-tuan dan puan-puan

Indonesia, Brunei Darussalam

Malaysia, Singapur, Timor Leste"

Juga terkadang memakai jargon "Kem...kem...ba.ba.bar. Meski dalam pendahuluan harus terdapat latar belakang materi yang akan di sampaikan, hal itu penulis perhatikan bahwa yang menjadi sebuah kata pengantar isi materi mereka adalah Ayat suci Al-qur'an baik dari video satu hingga sampai video ke sepuluh. Dilanjut kepada Arti ayat yang disertai dengan gerakan kemudian masuklah 
S. Nurjanah. Yaya, dan Rojudin

kepada isi pembahasan.

\section{Ketiga, Isi}

Isi adalah masalah pokok yang di uraikan dari judul. Hasil dari analisis penulis mulai dari video satu sampai sepuluh tidak ada yang keliru dengan artian antara judul dengan isi sangat berkesinambungan. Selain dari dalil dalam setiap ceramahnya selalu memakai hadits, sebagai salah satu contoh pembahasan mengenai "Jangan Takut Miskin":

"Hadirin wal hadirot... Dari Ibnu Mas'ud r.a Rasulullah Saw bersabda:

"Berinfaklah kamu wahai Bilal jangan takut hartamu itu di persedikit oleh Drat yang memiliki Arsy (HR. Baihaqi).

Lihatlah panduan Islam kitab suci Al-qur'an surat Al-Anbiya ayat 107 Allah berfirman:

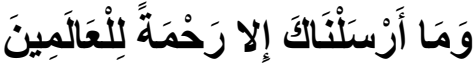

"Dan tiadalah Kami mengutus kamu, melainkan untuk (menjadi) rahmat bagi semesta alam".

"Lihatlah akhlak pemandu Islam Nabi Muhammad Saw ketika Fathu Makkah. Orang-orang kafir takut akan balas dendam umat Islam, namun ternyata Nabi Muhammad Saw memaafkan mereka bahkan menjalin keselamatan maasya? Allah. Islam masuk dan berkembang dengan damai, Islam phobia bisa dicegah bisa diatasi dengan dakwah bil hal menunjukan sikap Islami yang benar-benar sejati, dakwah bil lisan berusaha menjelaskan tentang Islam atau meluruskan hiwar dialog komunikasi dengan mereka, juga dakwah bil kolam dengan suatu tulisan”.

Di dalam isi juga terdapat ilustrasi dan contoh-contoh maupun cerita-cerita ringan yang berkaitan dengan judul, seperti yang terdapat dalam judul "In Heart On Heart':

"Bahkan dengan ilmu dan adab kecantikan dan ketampanan seseorang pun bisa bertambah. Conthnya ketika ada pemuda ganteng yang gayanya luar biasa tapi hatinya kurang baik, masyarakat pun akhirnya menilai kurang baik, namun ketika ada seorang santri yang berilmu dan beradab hatinya baik maasya Allah, masyarakat banyak yang bilang ganteng, bahkan banyak yang nyarter jadi calon menantu.Heuheuy....”.

\section{Keempat, Penutup}

Bagian penutup yaitu berupa simpulan. ILAL dalam ceramahnya dari video satu sampai sepuluh penulis teliti rata-rata mereka merangkai kata-kata dengan idenya sendiri yang dikemas menjadi lirik lagu, tetunya lirik tersebut bersangkutan 
dengan pembahasan. kecuali pada video ketiga (tidak memakai lirik lagu). Seperti:

"Hadirin wal hadirot mari kita stop hina menghina, hina menghina budaya yang hina, ejek mengejek budaya yang jelek. Om Ganteng musik...

Kekuatan lisan kita bukan untuk itu

Saling caci maki hina melulu

Pertahankan jaga lisanmu

Sesama muslim ta ta ta ta ta berseteru. Yeeaahhh”.

Kesimpulan dari video lainya yang tidak memakai lirik lagu:

"Kyai kami berkata: "lambat terhambat, malas terkiras, meleng terpelenting, mundur hancur, dan berhenti mati”.

Hadirin wal hadirot yang dirahmati Allah, oleh karena itu dari sekarang mari kita belajar disiplin. HAP”

Begitu pula Ilal selalu mengakhiri ceramahnya dari video satu sampai sepulah dengan kata-kata yang sama yaitu "Wallahu a'lam ihdinasyirotolmustaqim. Wa akhiron, undzur maa qoola walaa tandzur man qoola. Wassalamualaikum Warrahmatullahi wabarokatuh".

\section{Gaya bahasa Ilyasa dan Alyasa saat berceramah di ajang Aksi Asia Indosiar}

Gaya bahasa dapat dibatasi sebagai cara mengungkapkan pikiran melalui bahasa secara khas yang memperlihatkan jiwa dan kepribadian penulis (Keraf, 200 : 113).

Dalam ceramahnya, ILAL cenderung menggunakan logat bahasa Sunda karena mereka memang berasal dari Garut, Jawa Barat yang mayoritasnya menggunakan bahasa Sunda yang menjadi bahasa sehari-hari. Setelah melakukan penelitian dari video satu sampai sepuluh terdapat kalimat dan ungkapan yang mengandung gaya bahasa yang berpariasi.

\section{Gaya bahasa perbandingan}

Gaya bahasa perbandingan adalah gaya bahasa yang mengandung maksud perbandingan dua hal yang dianggap mirip atau mempunyai persamaan sifat (bentuk) dari dua hal yang di anggap sama. Gaya bahasa perbandingan meliputi hiperbola, metonimia, personifikasi, perumpamaan, metafora, sinekdoke, alusi, simile, asosiasi, eufemisme, pars pro toto, epitet eponym, dan hipalase. Dari 
sepuluh video ceramah ILAL terdapat beberapa kalimat yang meliputi jenis-jenis gaya bahasa perbandingan yaitu:

Kalimat "Abu al- Atahiya pun berkata "Man kaana muftahiron bil mali wanasabi fainnama fakhruna bil ilmi wal adabi" ketika orang-orang membanggakan harta dan nasab justru kita bangga dengan ilmu dan adab, ilmu dan adab pada diri seseorang akan menjadi cahaya yang berkilau memancarkan kecantikan seperti sun matahari, moon bulan and star bintang yang indah dengan cahayanya. Studio Aksi Asia pun menjadi indah dengan sorotan lampunya".

Kalimat tersebut mengandung majas "Hiperbola" yakni gaya bahasa yang mengandung pernyataan yang berlebihan dengan membesar-besarkan suatu hal (Keraf, 2007:113).

Kalimat "Dampak dari semena-mena, tempaan, timpaan, resah, rusuh, ribet, rebut, ribut! kebahagiaan susah di gapai, kedamaian susah tercapai, urusan susah selesai, masalah tak kunjung usai, tak di gunung tak di pantai, yang tak berdosa lemah lunglai, air mata berederai, malah ada yang bercerai derai, pelakunya malah santai-santai, lu olang sadar dongtai.

Kalimat tersebut mengandung majas "Epitet" yaitu acuan yang berusaha menyugestikan kesamaan antar orang, tempat, atau peristiwa (Keraf, 2007:141).

Kalimat "Sepandai-pandai tupai melompat pasti jatuh juga dan kita tidak bisa sembunyi dari Allab". Kalimat tersebut mengandung majas "Metafora" yakni semacam analogi yang membandingkan dua hal secara langsung, tetapi dalam bentuk yang singkat (Keraf, 2007:139).

Kalimat "Bagaikan kayu gaharu yang di bakar semakin harum". Kalimat tersebut mengandung majas "Perumpaan" yakni gaya bahasa yang membangkan sesuatu dengan hal lain, yang di anggap mempunyai sifat sama atau mirip.

Kalimat Kyai kami berkata: "lambat terhambat, malas terkiras, meleng terpelenting, mundur hancur, dan berhenti mati". Kalimat tersebut mengandung majas "Eponim" yakni gaya bahasa yang dipergunakan seseorang untuk menyebutkan hal atau nama dengan menghubungkan dengan sesuatu berdasarkan sifatnya.

\section{Gaya bahasa perulangan}

Gaya perulangan adalah gaya bahasa yang mengulang kata demi kata. Gaya bahasa perulangan meliputi: aliterasi, antanaklasis, anafora, anadiplosis, mesodiplosisi, epanalipsis, dan epizeukis. Diantara jenis gaya perulangan tersebut penulis teliti dari video satu sampai sepuluh yaitu:

Kalimat "Berinfaqlah wahai kau Bilal, jangan kamu takut harta dipersedikit oleh Dzat yang memiliki Arsy." (HR. Baihaqi). "karena Allab yang Maba Kaya akan mengganti" (QS. Saba: 39). Kalimat tersebut merupakan majas "Anafora” yakni berwujud perulangan kata pertama dalam kalimat berikutnya. Yang menjadi 
majasnya yaitu "berinfaklah-Jangan takut berinfak".

Kalimat "Hadirin yang berbahagia, mari kita awali segala urusan dengan Bissmillah. Dalam kalimat tersebut mengandung majas "Anadiplosis" yakni kalimat tersebut di ulang pada kalimat berikutnya (Keraf, 2007:128). Dan yang menjadi majasnya yaitu kata "Bissmillah".

Kalimat "Daripada kita meminta ke paranormal alangkah baiknya kita meminta kepada Allah dan curhat kepada ustadz, curhat dong ma, iya dong.." solusinya yakni harus rajin berinfak. "Memang saja apabila kita berinfaq 200rb diinfaqkan lagi $100 \mathrm{rb}$ sisanya tinggal $100 \mathrm{rb}$, tapi $100 \mathrm{rb}$ yang diinfaqkan akan melebihi 100rb yang disimpan". kalimat yang menjadi majasnya yaitu "berinfakdiifakan-berinfak" dan ini merupakan majas "Mesodiplosis" yakni gaya bahasa yang menggunakan pengulangan di tengah-tengah baris atau kalimat secara berurutan (Nurdin, 2002:29)

Kalimat "Memang jika berinfaq 200rb diinfaqkan lagi 100rb sisanya tinggal 100rb, tapi 100rb yang diinfaqkan akan melebibi 100rb yang disimpan”. Kalimat tersebut adalah majas "epizeukis" yaitu yang bersifat langsung dari kata-kata yang dipentingkan dan di ulang beberapa kali sebagai penegasan. Hal ini menyatakan bahwa yang menjadi majasnya adalah kata "infak".

Kalimat "Sesama muslim saling minano saling membina yes, saling minano saling milara yes, saling minano saling menjaga yes, saling minano saling menjaga yes". Kalimat di atas termasuk kepada majas "Aliterasi" yaitu gaya bahasa yang memanfaatkan kata-kata yang bermulanya sama bunyinya.

\section{Gaya bahasa sindiran}

Gaya bahasa sindiran yaitu acuan yang ingin mengatakan sesuatu dengan maksud berlainan dari isi yang terkandung dalam rangkaian kata-kata. Gaya bahasa sindiran meliputi: sinisme, inneundo, melosis, sarkasme, satire, dan antifrasis. Berikut adalah kalimat yang mengandung jenis-jenis dari gaya bahasa sindiran pada ceramah ILAL dari video satu sampai sepuluh:

Kalimat "Indonesia itu adalah Negara yang kebanyakan orang muslim bahkan terbesar di dunia lebih dari 230 juta Jiwa, tetapi pedang pasukan muslim mana yang di hunuskan di Indonesia begitu pun dengan Darussalam, Malaysia, Singapur, Timorleste". Pada kalimat tersebut mengandung majas "Sarkasme" karena kalimat tersebut merupakan penggunaan kata-kata yang keras dan kasar untuk menyindir atau mengkritik.

Kalimat "wee and family harus ingat, orang yang dihina pasti memiliki kelebihan yang tidak dimiliki orang lain, jika ada yang mencaci maki menghina sebenarnya dia yang hina". Kalimat tersebut mengandung majas "Satire" yaitu majas dengan gaya bahasa yang berbentuk penolakan dan mengandung kritikan dengan maksud agar sesuatu yang salah dicari kebenaranya (Nurdin, 2002:28). 
Kalimat "Wee and family pasti menginginkan kecantikan, tapi kurang tepat jika terlau memikirkan tampilan luar tapi lupa dengan tampilan hati”. Kalimat tersebut juga termasuk majas "satire".

Kalimat "Seharusnya sesama manusia, apalagi saudara, yang satu agama, seiman dan taqwa, harus saling menjaga, harus saling membina, kaya kita berdua". Kalimat tersebut mengandung majas "Inneundo" yakni sindiran dengan mengecilkan kenyataan yang sebenarnya (Keraf, 2007:144).

Kalimat "Sesungguhnya kecantikan yang sejati ada pada perhiasan hati, ilmu, dan adab". Kalimat tersebut mengandung majas "Melosis" sebab merupakan gaya bahasa yang mengandung pernyataan merendah dengan tujuan menekankan atau mementingkan hal yang dimaksud agar lebih berkesan dan bersifat ironis.

Kalimat "Umat Islam yang kadang terlihat tidak disiplin, terbelakang dan lain-lain". kalimat tersebut merupakan gaya bahasa sindiran yang mengandung majas "Sinisme" yakni majas tersebut sebagai sindiran yang berbentuk kesangsian, yang mengandung ejekan terhadap keikhlasan dan ketulusan hati (Keraf, 2007:143).

\section{Gaya bahasa pertentangan}

Gaya bahasa pertentangan adalah gaya bahasa yang maknanya bertentangan dengan kata-kata yang ada. Gaya bahasa ini meliputi: paradoks, antitesis, litotes, oksimoron, histeron prosteron, dan okupasi. Diantara video ceramah ILAL satu sampai sepuluh yang mempunyai jenis gaya bahasa pertentangan yaitu:

Kalimat "Dipondok kami ada selogan "Makan untuk hidup, bukan hidup untuk makan" (eat to live, not live to eat). Kalimat tersebut merupakan majas "Histeron Prosteron" yakni gaya bahasa yang berwujud kebalikan dari sesuatu yang logis. Kalimat "Guru kami berkata: "Jangan merasa pintar tapi pintar merasa". Pada kalimat tersebut termasuk majas "Oksimoron" yakni gaya bahasa yang antar bagianya menyatakan sesuatu yang bertentangan.

Kalimat "Contohnya ketika ada pemuda ganteng yang gayanya luar biasa tapi hatinya kurang baik, masyarakat pun akhirnya menilai kurang baik, namun ketika ada seorang santri yang berilmu dan beradab hatinya baik maasya Allah, masyarakat banyak yang bilang ganteng, bahkan banyak yang nyarter jadi calon menantu". Kalimat pada paragraf tersebut juga merupakan majas "Paradoks" yaitu gaya bahasa yang bertentangan namun nyata dengan fakta yang ada.

Kalimat "Tidaklah menyepelekan amalan sekecil apapun, mungkin ridho Allah terletak disana, begitu pun tidak menyepelekan maksiat sekecil apapun, mungkin murka Allah terletak disana". Kalimat dari paragraf tersebut merupakan majas "Okupasi" yakni gaya bahasa pertentangan yang mengandung bantahan, tetap disertai penjelasan.

Kalimat "Makan berlebihan hanya membuat syetan senang, sedangkan kita 
mendapat penderitaan perut mengembang". Kalimat tersebut mengandung majas "Litotes" yaitu gaya yag mengandung pernyataan yang dikecil-kecilkan dan di kurangi dari pernyataan sebenarnya.

\section{Gaya bahasa penegasan}

Gaya bahasa penegasan yaitu gaya bahasa yang mengulang kata-katanya dalam satu baris kalimat. Gaya bahasa penegasan meliputi repetisi dan paralelisme. Terdapat beberapa kalimat dari ceramah ILAL yang mengandung jenis gaya bahasa penegasan diantaranya:

Kalimat "apabila kita merasakan takut miskin sesungguhnya itu godaan syetan yang harus dihindari. Kita lbisa saksiakan di kalangan masyarakat orang yang takut miskin itu seringkali melakukan pelanggaran, bahkan melakukan kemusyrikan seperti adanya orang yang mendatangi paranormal". Kalimat tersebut adalah majas "paralesisme" yakni semacam gaya bahasa yang berusaha mencapai kesejajaran dalam pemakaian kata-kata atau frasa-frasa yang menduduki fungsi yang sama dalam bentuk gramatikal yang sama (Nurdin, 2002:22).

Kalimat "Jika ingin mendapatkan ridho Allah, ikutilah jejak Rasulullah, jadikan sebagai contoh, beriman dengan kokoh, tidak mudah roboh, berfikir tidak bodoh, bertindak tidak ceroboh, berbuat tidak senonoh, dalam pergaulan buruk jangan sampai jatoh, jika ada yg ngajak khalwat kesana kesini ogah gituloohh". Kalimat di atas mengandung majas "Repetisi" yakni perulangan bunyi, suku kata, kata atau bagian kalimat yang dianggap penting untuk memberi untuk memberi tekanan dalam konteks yang nyata.

Kalimat "Bissmillahirrohmaanirrohim adalah lafadz yang sedikit namun mengandung arti yang luas dan makna yang sangat mendalam. Imam annas syafii di dalam tafsirnya telah mengatakan bahwa semua makna Al-qur'an terkumpul pada surat Al-fatihah, dan makna Al-fatihah terkumpul dalam Bassmallah dan makna Bassmallah terkumpul pada huruf ب nya. Sebagain ulama menambahkan dan makna ب terkumpul pada titiknya yang menunjukan tunggal tiada berbilang dialah Allah yang maha esa tiada andinganya". Pada paragraf tersebut juga mengandung majas "Repetisi" seperti yang telah di jelaskan pada point di atas.

Kalimat "Islam melarang penganiayaan, kedzoliman atau segala perbuatan yang menuju prilaku semena-mena, baik kepada sama muslim atau non muslim, baik kepada yang di kenal atau tidak di kenal, baik kepada makhluk berakal atau tidak berakal". Kalimat tersebut juga mengandung majas "Repetisi".

\section{PENUTUP}

Berdasarkan dari hasil pemaparan yang telah disampaikan, maka dapat ditarik kesimpulan sebagai berikut: Pertama, Gestur Ilyasa dan Alyasa saat berceramah 
yaitu meliputi badan yang berdiri tegap, namun terkadang membungkuk, sesekali mereka menghadap kepada audiens, dan sering berpindah tempat sesuai apa yang mereka sampaikan. Adapun mengenai penampilan dan pakaian mereka berpenampilan rapi layaknya orang kembar dengan memakai pakaian yang sama keduanya. Sedangkan gerakan tanganya yaitu mengikuti sesuai apa yang disampaikan, Kadang menggunakan telunjuk ke atas, kanan, kiri, dan ke depan dengan kompak dan bergandengan di saat menyebutkan "kami berdua".

Kedua, Struktur materi yang disampaikan meliputi Judul, pendahuluan, isi, dan penutup. Judul yang penulis teliti terdapat sepuluh judul, kemudian pendahuluan dengan ciri khasnya ILAL setelah memberikan salam dan muqiddimah selalau di awali dengan sapaan "Nurrobib bisaadah majlisi tabkim, kama nurrobib bi sayyidah wa saadah majlisi ta'kib". "Hadirin ejeung hadirot, tuan-tuan dan puan-puan Indonesia, Brunei Darussalam Malaysia, Singapur, Timor Leste" Juga terkadang memakai jargon "Kem...kem...ba.ba.bar. kemudian bagian isi, yang mana isi tersebut mulai dari video satu sampai sepuluh menjadi bahan analisis peneliti yang telah dipaparkan pada jawaban dari rumusan masalah. Selanjutnya penutup yang mengakhiri ceramahnya, setelah memberikan kesimpulan ILAL selalu menutup ceramahnya dengan kata-kata yang sama sesuai yang penulis teliti dari video satu sampai sepuluh yaitu: "Wallahu a'lam ibdinasyirotolmustaqim. Wa akbiron, undzur maa qoola walaa tandzur man qoola. Wassalamualaikum Warrabmatullabi wabarokatub".

Ketiga, Gaya bahasa yang digunakan mengandung beberapa majas dari gaya bahasa perbandingan, gaya bahasa perulanagn, gaya bahasa sindiran, gaya bahasa pertentangan, dan gaya bahasa penegasan. Serta mengandung diksi atau pemilihan kata yang tepat dan enak di dengar sehingga mampu menarik pehatian audiens.

Adapun dalam penelitian ini, ada beberapa saran yang telah peneliti sampaikan diantaranya yaitu: Pertama, Penulis mengharapkan peserta da'i muda ini baik yang juara ataupun tidak tetaplah menjadi tongkat estafet untuk memberi dakwah kepada masyarakat nantinya, dalam artian tidak hanya berdakwah dalam ajang perlombaan saja. Kedua, Bagi para da'i dan da'iyah jangan patah semangat untuk menggali potensi diri sebagai pendakwah, kuasai teknik retorika supaya dapat menampilkan ceramah yang maksimal dan bisa di contoh bagi generasi muda selanjutnya. Ketiga, Supaya isi ceramah kita terkesan oleh audiens, maka cobalah untuk mengemas sebuah kisah kita ataupun pengalaman kita yang menyenangkan, unik, dan menantang. 


\section{DAFTAR PUSTAKA}

Abidin, Y.Z. (2017), Pengantar Retorika, Bandung: Pustaka Setia.

Dewi, F. U. (2003), Public Speaking Kunci Sukses Bicara di depan Publik: Teori Praktik, Yogyakarta: Pustaka Pelajar.

Dulwahab, E. (2016), Rebranding Dakwah di Media. ANIDA: Aktualisasi Nuansa Ilmu Dakwah, Volume 15 No. (2): 1, Web. 21 Agustus 2019.

Imam Zaidillah, A. (2005), Strategi Dakwah Dalam Membentuk Da'i dan Khotib Profesional, Jakarta: Kalam Mulia.

Keraf, G. (2007), Diksi dan Gaya Bahasa, Jakarta: Gramedia.

Moede, N. (2001), Buku Pintar Dakwah, Jakarta: Intermedia dan Ladang Pustaka.

Muhyiddin, A. (2017), Retorika Dakwah Mamah Dedeh dalam Acara "Mamah \& Aa Beraksi" di Indosiar. Ilmu Dakwah, Academic Journal for Homiletic Studies, Volume 11 No. (2): 219-234, Web. 06 Agustus 2019.

Mulyana, D. (2017), Ilmu Komunikasi, Bandung: Remaja Rosdakarya.

Nurdin Dkk, A. (2002), Intisari Bahasa dan Sastra Indonesia, Bandung: Pustaka Setia.

https://id.wikipedia.org/wiki/Akademi_Sahur_Asia_Posberitakota.

Prastiti, W.D. (2018), Gaya Retorika Dakwah Il \& Al Dalam Tajuk "Jangan Takut Miskin" Pada ajang Aksi Asia 2018. Skripsi. UIN Sunan Ampel Surabaya.

Rahmat, J. (2011), Retorika Modern Pendekatan Praktis, Bandung: Remaja Rosdakarya.

Syukir, A. (1983), Dasar-Dasar Strategi Dakwah Islam, Surabaya: Al Ikhlas.

Wahid, A. (2015), Fenomena Dakwah di Televisi (kajian dalam dunia infortanment), Tabligh: Jurnal Komunikasi dan Penyiaran Islam, Volume 16 No. (1): 1, Web. 21 Agustus 2019. 